\title{
INFLUENCE OF INSURANCE ON COMPETITIVENESS OF FOOD ENTERPRISES IN UKRAINE
}

\author{
Lada Shirinyan ${ }^{1}$, Mykhailo Arych ${ }^{2}$, Hanna Rohanova ${ }^{3}$ \\ ${ }^{1}$ Ph.D. in Economics, Doctor of Economic Sciences, Professor, Head of the Department of Finance, National University of \\ Food Technologies, 68 Volodymyrska str., Kyiv, Ukraine; tel. №: +38-097-297-79-63; e-mail: ladashirinyan@ukr.net \\ ${ }^{2}$ Ph.D. in Economics, Associate Professor, National University of Food Technologies, Kyiv, Ukraine, e-mail: \\ mykhailo.arych@gmail.com \\ ${ }^{3}$ Ph.D. in Economics, Associate Professor,National University of Food Technologies, Kyiv, Ukraine, \\ e-mail: hanna.rohanova@gmail.com
}

Received 1407 2020; Accepted 04112020

\begin{abstract}
Food industry enterprises (FIEs) are important players in the agricultural sector and use insurance as the tool to protect the business. The actual issue is determining the influence of insurance. The paper is devoted to the analysis of the influence of insurance on key indicators of the activity of FIEs from the viewpoint of use of insurance by the insurance market participants. The investigation methodology is based on the concept of 'competitiveness' of an enterprise explaining the ability to operate profitably and meet the competition. The aim of the work is to analyze the relationship between insurance costs and indicators of efficiency and competitiveness of Ukraine's FIEs. Hypotheses concerning the propensity of FIEs with higher competitiveness to use insurance and influence of insurance on key indicators of FIEs activity have been formulated and tested. Economic-statistical analysis and correlation-regression analysis have been performed due to Microsoft Office 2013 software packages. The hypothesis about the existence of dependence between the competitiveness of FIEs and the portion of money allocated by FIEs for insurance is confirmed only for FIEs with high efficiency of business activity.
\end{abstract}

Keywords: insurance, competitiveness, food industry, assets, equity, sales, costs.

JEL Classification: G22, L66, Q12, Q14, Q18.

\section{Introduction}

Food industry enterprises (hereinafter as FIEs) are key players in the agricultural sector (hereinafter as ACS) of Ukraine and need to protect business from unwanted risks influencing on their financial results. Insurance can be an effective tool to protect FIEs. The actual issue is determining the effect of such interaction and finding the influence of insurance on key indicators of FIEs activity and regularities that are being formed on the market under current conditions.

\section{Literature review}

The insurance impact on FIEs' performance can be both positive and negative. For example, Akinrinola and Okunola (2014) pointed the positive insurance effect on Nigeria's agricultural production. Friedli (2017) summarized the most important findings of monitoring of food consumption patterns, regulatory changes and trends in litigation. Zhao and Preckel (2016) showed, on a basis of empirical studies, the effect of crop insurance on farmers' income. Lorant and Farkas (2015) focused on risk management in the agricultural

Copyright () 2021 Author(s), published by Vytautas Magnus University. This is an open access article distributed under the terms of the Creative Commons Attribution Non-Commercial 4.0 (CC BY-NC 4.0) license, which permits unrestricted use, distribution, and reproduction in any medium provided the original author and source are credited. The material cannot be used for commercial purposes. 
sector. Barath, Dokucheva and Ferto (2017) hypothesized the existence of reciprocal causation between crop insurance use and the economic performance of farms. Zibor-Nemes, Fogarasi, Molnar, Kemeny (2018) investigated the role of crop insurance among Hungarian crop farmers and the responses to the introduction of the two-scheme risk management system.

The impact of insurance on the activities of FIEs of Ukraine remains largely unaddressed. Kvasko (2017) notes that the problem of choosing a universal indicator and competitiveness factors for ACS remains unresolved. Semenenko (2017) analyzes the level of inter-industry competition and notes that one of the key problems in ACS is the insurance of investments against noncommercial risks. Lobova (2014) gives the list of risks in ACS and pays attention on the indicators of evaluation of the effectiveness of insurance operations. As we know, the quantitative analysis of the insurance costs impact on FIEs' competitiveness still remains unsolved.

\section{The aim of the study}

The purpose of this paper is to analyze the relationship between the insurance costs, performance and competitiveness indicators of FIEs in Ukraine. The main hypothesis of the study is formulated as follows: FIEs with higher competitiveness are more prone to insurance. The second hypothesis is related to the influence of insurance on the key indicators of FIEs activity and existence of correlations between FIEs' insurance costs and main economic indicators of FIEs' activities.

\section{Materials and methods}

In order to create a database of insurance companies' expenses for the time period 20132017, data from more than 500 FIEs of Ukraine was analyzed. We used the annual financial reports of FIEs, private and official public
Internet resources, information from the official website of the Official Body 'Stock Market Infrastructure Development Agency of Ukraine' (Official, 2020). Unfortunately, during the processing such data, it turned out that information on insurance costs for many FIEs is not provided or such information is provided only for few years of the proposed study. Due to mentioned Agency we used data in Section "Notes to the Financial Statements Compiled in Accordance with International Financial Reporting Standards" and identified information on income and insurance costs for familiar 13 FIEs in Ukraine for the period 2013-2017. Hereby, in most cases that indicator is designated as "Insurance" or "Insurance costs", etc.

It is worth noting that we deal with the concept of 'competitiveness' of an enterprise. Competitiveness is associated with the market mechanism and it has been described by many authors. It explains the ability to produce and sell products in order to operate profitably and meet the competition.

According to the Porter's theory (Porter, 2012), competitiveness depends on long run productivity and requires a business environment that supports continual innovation in products, processes and management. The corresponding approach is frequently used by the researchers for the competitive advantage of nations. Buckley, Pass and Prescott (1988) conceptualized model for firm's competitiveness. Authors proposed such measures as: market share, technological development, long-run price and cost effectiveness, closeness to customer, investment strategy, commercialization of technology and management attitude to internalization. Thus, the concept may refer to different levels of aggregation: national, local, etc., as well as to individual companies. Definitions are usually applied to the best agents whereas in the marketplace, there exist different economic agents. That is why the competitiveness should be defined as a relative characteristics of one object with respect to comparable objects on the market. 


\section{Management Theory and Studies for Rural Business and Infrastructure Development}

eISSN 2345-0355. 2021. Vol. 43. No. 1: 05-12

Article DOI: https://doi.org/10.15544/mts.2021.01

In our work the competitiveness determines the degree of advantage for a set of indicators of one FIE with respect to the same set of indicators for another FIE and describes the ability to maintain competition in the market. It is also worth noting that such concept correlates with the concept of 'efficiency', since both serve as factors for successful business development (Shirinyan, Shirinyan, 2019, p.38). Hereby, both concepts deal with benefits and results per unit of costs and one needs to find correlations of results, incomes and costs due to key indicators.

Key research indicators. The competitiveness of an enterprise in a market can be estimated due to a share of market coverage:

$$
\mathrm{S}=100 \% \cdot \mathrm{NI} / \mathrm{NI}_{\mathrm{ALL}},
$$

where $\mathrm{S}$ - share of an entity in a net income of all enterprises in a market (in \%), NI - net income of a given enterprise (in UAH), $\mathrm{NI}_{\mathrm{ALL}}-$ net income of all enterprises in a market. (The value NI is determined by the line 2000 of form 2 of the annual report on financial results of FIEs called 'Income Statement' and defines a net revenue from sale).

Let's turn on key activity indicators of FIEs. One of the main indicators is the return on assets (further as ROA), which is calculated in per cent by the formula:

$$
\mathrm{ROA}=100 \% \cdot \mathrm{NP} / \mathrm{A} .
$$

Here NP is a net profit of FIE and A assets (in UAH). For a positive result, net profit is determined by line 2350 of form 2 of the annual report on financial results of the FIEs and, for the case of losses, it is found by line 2355 of the 'Income Statement'.

In financial science, return on equity (further as ROE) is considered as another possible indicator of performance. The formula for ROE in per cent is the following:

$$
\mathrm{ROE}=100 \% \cdot \mathrm{NP} / \mathrm{E} .
$$

Here, $\mathrm{E}$ is an equity (which is determined in UAH by line 1495 of form 1 of the annual financial statements of an enterprise called 'Statement of financial state').

For FIEs it is necessary to consider the return on sales indicator (further as ROS) according to the formula:

$$
\mathrm{ROS}=100 \% \cdot \mathrm{NP} / \mathrm{NI}
$$

The last macroeconomic indicator in our study will be the share of net income of the enterprise in GDP of Ukraine (further as penetration ratio, $\mathrm{PR})$ :

$$
\mathrm{PR}=100 \% \cdot \mathrm{NI} / \mathrm{GDP} .
$$

Here, PR is the share of one enterprise (in $\%$ ) in GDP, GDP is the value of the gross domestic product of Ukraine (in UAH).

In our work we introduce insurance cost as a new factor of competitiveness for FIE. Insurance costs are the part of total costs, and therefore it would be expedient to analyze their share in total costs by the formula:

$$
\mathrm{IS}=100 \% \cdot \mathrm{IC} / \mathrm{PC} \text {. }
$$

Here IS - share of insurance cost in total costs of a given FIE (in \%), IC - insurance costs of a company, PC - production costs (costs of sold products) of a company. Insurance costs IC are determined due to notes to the financial statements, prepared in accordance with international financial reporting standards. The value of $\mathrm{PC}$ is

Copyright (C) 2021 Author(s), published by Vytautas Magnus University. This is an open access article distributed under the terms of the Creative Commons Attribution Non-Commercial 4.0 (CC BY-NC 4.0) license, which permits unrestricted use, distribution, and reproduction in any medium provided the original author and source are credited. The material cannot be used for commercial purposes. 
determined by line 2050 of form 2 of the annual 'Income Statement'.

Let's pass on the hypothesis about the impact of insurance on the FIEs' activities. To do this, we perform a correlation-regression analysis for the given indicators according to the available data. We use economic-statistical analysis and correlation-regression analysis. An economic-statistical analysis and correlation analysis are conducted using Microsoft Office 2013 software packages. The regression equations are used in linear type. Additionally, we determine the rate of change of insurance costs for the selected list of enterprises.

Correlation-regression analysis. We selected two target research functions: i) insurance costs of FIEs (IC in UAH as function $\mathrm{Y}_{1}$ ); ii) the relative share of insurance costs in the total expenses of FIEs (IS in \% as function $\mathrm{Y}_{2}$ ). On the other side, we considered six factor variables $\left(\mathrm{X}_{1}-\mathrm{X}_{6}\right)$ as arguments of the model. Hereby, only one factor has units of measurement UAH, all others are measured in percentage (table 1).

Table 1. Microeconomic target functions and factors for the regression analysis (developed by the authors)

\begin{tabular}{|c|c|c|}
\hline Marking & Explanation & Unit of measure \\
\hline \multicolumn{3}{|c|}{ Target functions } \\
\hline $\mathrm{Y}_{1}$ & $\mathrm{IC}$ & thousand UAH \\
\hline $\mathrm{Y}_{2}$ & $\mathrm{IS}$ & $\%$ \\
\hline \multicolumn{3}{|c|}{ Factor variables } \\
\hline $\mathrm{X}_{1}$ & $\mathrm{NI}$ & thousand UAH \\
\hline $\mathrm{X}_{2}$ & $\mathrm{~S}$ & $\%$ \\
\hline $\mathrm{X}_{3}$ & $\mathrm{ROA}$ & $\%$ \\
\hline $\mathrm{X}_{4}$ & $\mathrm{ROE}$ & $\%$ \\
\hline $\mathrm{X}_{5}$ & $\mathrm{ROS}$ & $\%$ \\
\hline $\mathrm{X}_{6}$ & $\mathrm{PR}$ & $\%$ \\
\hline
\end{tabular}

According to the procedure, for each FIE, the factors having a high pairwise correlation and those having a low correlation with the resulting indicator have been rejected from. Only independent influential factors are included in the final regression equations. Each regression equation has a linear form:

$$
\begin{array}{r}
\mathrm{Y}_{1}=\mathrm{Y}_{0}+f\left(\mathrm{X}_{1}, \mathrm{X}_{2} \ldots, \mathrm{X}_{6}\right)=\mathrm{Y}_{0}+\mathrm{a}_{1} \mathrm{X}_{1},+\mathrm{a}_{2} \mathrm{X}_{2}+\mathrm{a}_{3} \mathrm{X}_{3}+ \\
\mathrm{a}_{4} \mathrm{X}_{4}+\mathrm{a}_{5} \mathrm{X}_{5}+\mathrm{a}_{6} \mathrm{X}_{6},
\end{array}
$$

where $\mathrm{Y}_{0}$ is the free coefficient; $\mathrm{a}_{1}, \mathrm{a}_{2} \ldots, \mathrm{a}_{6}$ are correlation coefficients.

\section{Results and discussion}

Let us first consider general information about selected FIEs (names are listed further) in order to have average estimation values of the sample.
The largest shares $\mathrm{S}$ and $\mathrm{PR}$ are determined for PJSC 'Karlsberg Ukraine' (averaged as $\mathrm{S}=1.2 \%, \mathrm{PR}=0.2 \%$ ) and the smallest similar values are found for PJSC 'Sumy Food Products Factory': averaged as $\mathrm{S}=0.028 \%$ and $\mathrm{PR}=0.005 \%$.

The highest positive values of performance indicators ROA, ROS and ROE are obtained for PJSC 'Karlsberg Ukraine'. Some other entities (PJSC 'Obolon', PJSC 'Kyivkhlib', PJSC 'Sumy Food Products Factory', PJSC 'Pologovsky Oil Extraction Plant' and PJSC 'Kremenchug Confectionery Factory') have negative values for certain periods which means losses for companies.

The largest share of insurance costs is related to PJSC 'Pologovsky Oil Extraction Plant' (with IS $=2.173 \%$ in 2016) and the lowest values appears for PJSC 'Kyivkhlib' (from IS $=0.007 \%$ in 2016 to IS $=0.027 \%$ in 2014). 


\author{
Management Theory and Studies for Rural Business and Infrastructure Development \\ eISSN 2345-0355. 2021. Vol. 43. No. 1: 05-12 \\ Article DOI: https://doi.org/10.15544/mts.2021.01
}

On the average, PJSC 'Pologovsky Oil Extraction Plant', PJSC 'Karlsberg Ukraine', Private JSC 'Kyiv Confectionary Factory 'Roshen' have greatest values of the share of insurance costs IS.

Hypothesis 1 - the results on insurance costs. The corresponding analysis allows to construct regression equations for the selected
FIEs (table 2) and make the appropriate scientific reasonable conclusions.

First, the data show that there is only one case (PJSC 'Kharkiv Biscuit Factory') when the regression equation does not exist: the correlation between factors $X$ and target function $Y$ was less than 0.5 . Secondly, one can see that in five cases the free coefficient $Y_{0}$, described in formula (7), is less than zero.

Table 2. Multivariate regression equations for the sample of FIEs of Ukraine (Source: Author's calculations based on official data of companies (Official, 2020; State, 2020))

\begin{tabular}{|c|c|}
\hline The name of FIEs & Regression equations for the $\mathrm{Y}_{1}=\mathrm{IC}$ : \\
\hline PJSC 'Karlsberg Ukraine' & $7027.7+0.002 \cdot \mathbf{X}_{1}+530.1 \cdot \mathbf{X}_{2}-29650.0 \cdot \mathbf{X}_{\mathbf{6}}$ \\
\hline PJSC 'Obolon' & $-4266.5+0.001 \cdot \mathbf{X}_{1}+2.448 \cdot \mathbf{X}_{3}+161.5 \cdot \mathbf{X}_{5}-0.2 \cdot \mathbf{X}_{6}$ \\
\hline PJSC 'Kyivkhlib’ & $906.6-0.0002 \cdot \mathbf{X}_{\mathbf{1}}-0.839 \cdot \mathbf{X}_{\mathbf{4}}-2680.1 \cdot \mathbf{X}_{\mathbf{6}}$ \\
\hline PJSC 'Pologovsky Oil Extraction Plant' & $-30754.9+0.01 \cdot \mathbf{X}_{1}+277802.9 \cdot \mathbf{X}_{\mathbf{6}}$ \\
\hline PJSC ‘APK-INVEST’ & $-210.9+0.0006 \cdot \mathbf{X}_{1}+13228.2 \cdot \mathbf{X}_{\mathbf{6}}$ \\
\hline PJSC 'Zhytomyr Butter Factory' & $-10.3+0.0003 \cdot \mathbf{X}_{1}$ \\
\hline PJSC 'Kharkiv Biscuit Factory’ & $177.3+0.0000315764 \cdot \mathbf{X}_{\mathbf{1}}-2.1 \cdot \mathbf{X}_{\mathbf{5}}$ \\
\hline PJSC 'Dniprovsky Starch and Syrup Integrated Works' & $4337.7+117.9 \cdot \mathbf{X}_{\mathbf{3}}-142676.8 \cdot \mathbf{X}_{\mathbf{6}}$ \\
\hline PJSC 'Kyiv Confectionary Factory ‘Roshen’ & $114.5+10146.7 \cdot \mathbf{X}_{2}$ \\
\hline PJSC 'The House of Vintage Cognacs 'Tauria' & $359.1-0.0003 \cdot \mathbf{X}_{\mathbf{1}}-5.9 \cdot \mathbf{X}_{\mathbf{3}}$ \\
\hline PJSC 'Confectionery Factory 'Kharkivyanka' & $\begin{array}{l}\text { The correlations between the factors } \mathrm{X} \text { and function } \mathrm{Y} \\
\text { are less than } 0.5\end{array}$ \\
\hline PJSC 'Kremenchug Confectionery Factory’ & $-894.4+31172.8 \cdot \mathbf{X}_{2}-51.3 \cdot \mathbf{X}_{4}$ \\
\hline PJSC ‘Sumy Food Products Factory’ & $39.5+0.0001 \cdot \mathbf{X}_{1}+1.0 \cdot \mathbf{X}_{3}$ \\
\hline
\end{tabular}

Let us consider how often the factor appears in regression equations (table 3). One can see that factor $X_{1}$ is presented in 9 regression equations, $\mathrm{X}_{6}-$ in 6 equations, $\mathrm{X}_{3}-$ in 4 equations, $\mathrm{X}_{2}-$ in 3 equations, $\mathrm{X}_{4}$ and $\mathrm{X}_{5}-$ in 2 equations. For example, for three FIEs the indicator $X_{2}=S$ has the greatest influence on function $\mathrm{Y}_{1}$ : on the overage, the increasing for $1 \%$ of factor $\mathrm{S}$ leads to increasing the amount of insurance costs by an average of 13.950 million of UAH.
Further, regression coefficients may have different signs: for example, unlike other FIEs, the regression coefficient of PJSC 'The House of Vintage Cognacs 'Tauria' for factor variable $\mathrm{X}_{1}$ is negative. Similar results are obtained also for other regression coefficients.

The data in Table 3 confirm only partially the first hypothesis of the study on the propensity of the FIEs with high competitiveness to use insurance. The corresponding influence is revealed between the

Copyright (C) 2021 Author(s), published by Vytautas Magnus University. This is an open access article distributed under the terms of the Creative Commons Attribution Non-Commercial 4.0 (CC BY-NC 4.0) license, which permits unrestricted use, distribution, and reproduction in any medium provided the original author and source are credited. The material cannot be used for commercial purposes. 
indicators $\mathrm{X}_{2}=\mathrm{S}$ and $\mathrm{Y}_{1}=\mathrm{IC}$. As one can see, such correlations exist only in three cases with positive values of correlation coefficient

Table 3. The appearance of factor variables in regression equations for $\mathrm{Y}_{1}=\mathrm{IC}$ (Source: Author's calculations based on data (Official, 2020; State, 2020))

\begin{tabular}{|c|c|c|c|c|c|c|}
\hline \multirow{2}{*}{$\begin{array}{l}\text { The value of the } \\
\text { coefficient }\end{array}$} & \multicolumn{6}{|c|}{ The value of the regression coefficient for a given factor $X$} \\
\hline & $\mathrm{X}_{1}=\mathrm{NI}$ & $\mathbf{X}_{2}=\mathbf{S}$ & $\mathrm{X}_{3}=\mathrm{ROA}$ & $\mathrm{X}_{4}=\mathrm{ROE}$ & $\mathrm{X}_{5}=\mathrm{ROS}$ & $\mathbf{X}_{6}=\mathbf{P R}$ \\
\hline Minimum & -0.0003 & 530.1 & -5.90 & -51.30 & -2.1 & -142676.8 \\
\hline Maximum & 0.010 & 31172.8 & 117.90 & -0.84 & 161.5 & 277802.9 \\
\hline Average & 0.0015 & 13949.9 & 28.86 & -26.07 & 79.70 & 17386 \\
\hline \multicolumn{7}{|c|}{$\begin{array}{c}\text { Frequency of appearance for the factor variables in regression equations } \\
\text { (number of cases from all available ones) }\end{array}$} \\
\hline Positive values & 7 from 9 & 3 from 3 & 3 from 4 & - & 1 from 2 & 2 from 6 \\
\hline Negative values & 2 from 9 & - & 1 from 4 & 2 from 2 & 1 from 2 & 4 from 6 \\
\hline
\end{tabular}

Regarding the correlations between insurance costs and key performance indicators, we see that such influence appears only for correlations between $\mathrm{X}_{3}=\mathrm{ROA}$ and $\mathrm{Y}_{1}=\mathrm{IC}$ : in 3 cases out of 4 with positive correlation coefficients.

Also, factor $\mathrm{X}_{1}=\mathrm{NI}$ has the highest frequency of occurrence and the corresponding impact on the resulting indicator $\mathrm{Y}_{1}=\mathrm{IC}$. Hence, the bigger is the net income of the FIE, the more money FIE spends on insurance.

The second most frequent factor is penetration ratio $\mathrm{PR}$ with mostly negative regression coefficients: the increasing of $P R$ is usually accompanied by decreasing of insurance costs $\mathrm{Y}_{1}=\mathrm{IC}$ and vice versa, which may be due to the fact that insurance costs reduce FIEs' net income.

Hypothesis 2 - the results on insurance costs share. Let us turn to the correlationregression analysis for the share of insurance costs in total costs, that is to target indicator $\mathrm{Y}_{2}=\mathrm{IS}$. The results for regression equations are presented in table 4. One can resume the following:

1.The regression equation is not formulated for one enterprise (PJSC 'Zhytomyr Butter Factory') because there do not exist correlations.

2. The free coefficients $Y_{0}$ are negative in 3 cases of the 12 equations.

3. Net income factor $X_{1}$ is present in 6 of the 12 regression equations, factors $\mathrm{X}_{3}$ and $\mathrm{X}_{6}-$ in 4 regression equations.

4. Different companies have different signs of regression coefficients for the same factor, as shown in Tables 4-5.

5. Factor $\mathrm{X}_{2}=\mathrm{C}_{1}$ has the biggest influence on indicator $\mathrm{Y}_{2}$ for the PJSC 'Kremenchug Confectionery Factory'. Hereby, $1 \%$ increase in $\mathrm{C}_{1}$ leads to $10.7 \%$ increase in $\mathrm{Y}_{2}=\mathrm{IS}$ and vice versa. For other FIEs, no effect of factor $\mathrm{X}_{2}$ is detected. 
Management Theory and Studies for Rural Business and Infrastructure Development

eISSN 2345-0355. 2021. Vol. 43. No. 1: 05-12

Article DOI: https://doi.org/10.15544/mts.2021.01

Table 4. Regression equations for the share of insurance costs for the selected FIEs (Source: Author's calculations based on official data of companies (Official, 2020; State, 2020))

\begin{tabular}{|c|c|}
\hline $\begin{array}{r}\text { The name of FIEs } \\
\end{array}$ & Regression equations for the $Y_{2}=I S:$ \\
\hline PJSC 'Karlsberg Ukraine' & $0.2-0.005 \cdot \mathbf{X}_{\mathbf{3}}+0.006 \cdot \mathbf{X}_{\mathbf{5}}$ \\
\hline PJSC 'Obolon' & $-0.4+3.70631 \mathrm{E}-08 \cdot \mathbf{X}_{\mathbf{1}}+0.01 \cdot \mathbf{X}_{\mathbf{5}}-0.5 \cdot \mathbf{X}_{\mathbf{6}}$ \\
\hline PJSC 'Kyivkhlib' & $0.04-1.21496 \mathrm{E}-08 \cdot \mathbf{X}_{\mathbf{1}}-0.0002 \cdot \mathbf{X}_{4}$ \\
\hline PJSC 'Pologovsky Oil Extraction Plant' & $-1.0+2.70449 \mathrm{E}-07 \cdot \mathbf{X}_{\mathbf{1}}+14.2 \cdot \mathbf{X}_{\mathbf{6}}$ \\
\hline PJSC 'APK-INVEST’ & $0.1-0.002 \cdot \mathbf{X}_{3}$ \\
\hline PJSC 'Zhytomyr Butter Factory' & There are no correlations between $\mathrm{X}$ and $\mathrm{Y}$ \\
\hline PJSC 'Kharkiv Biscuit Factory’ & $0.04-7.58516 \mathrm{E}-09 \cdot \mathbf{X}_{1}-0.2 \cdot \mathbf{X}_{\mathbf{2}}$ \\
\hline PJSC 'Dniprovsky Starch and Syrup Integrated Works' & $0.5+0.003 \cdot \mathbf{X}_{\mathbf{3}}-14.3 \cdot \mathbf{X}_{\mathbf{6}}$ \\
\hline PJSC 'Kyiv Confectionary Factory 'Roshen' & $0.2+0.02 \cdot \mathbf{X}_{4}+7.0 \cdot \mathbf{X}_{6}$ \\
\hline PJSC 'The House of Vintage Cognacs 'Tauria' & $0.7-9.00822 \mathrm{E}-07 \cdot \mathbf{X}_{1}$ \\
\hline PJSC 'Confectionery Factory “Kharkivyanka' & $0.03+8.425 \mathrm{E}-09 \cdot \mathbf{X}_{1}$ \\
\hline PJSC 'Kremenchug Confectionery Factory’ & $-0.6+21.6 \cdot \mathbf{X}_{2}-0.1 \cdot \mathbf{X}_{4}$ \\
\hline PJSC 'Sumy Food Products Factory' & $0.3+0.03 \cdot \mathbf{X}_{3}$ \\
\hline
\end{tabular}

The results do not confirm the second hypothesis regarding correlations between the share of insurance costs IS and key performance indicators ROA, ROE, ROS. The effect is obtained only for 4 correlations between $\mathrm{X}_{3}=$ ROA and $\mathrm{Y}_{2}=\mathrm{IS}$, whereas only in 2 cases such correlations have positive values of correlation coefficients.

Table 5. The appearance of factor variables in regression equations for the $\mathrm{Y}_{2}=\mathrm{IS}$ (Source: Author's calculations based on data (Official, 2020; State, 2020)

\begin{tabular}{|c|c|c|c|c|c|c|}
\hline \multirow{2}{*}{$\begin{array}{l}\text { The value of the } \\
\text { coefficient }\end{array}$} & \multicolumn{6}{|c|}{ The value of the regression coefficient for a given factor $X$} \\
\hline & $X_{1}=\mathbf{N I}$ & $\mathbf{X}_{2}=\mathbf{S}$ & $\mathrm{X}_{3}=\mathrm{ROA}$ & $\mathrm{X}_{4}=\mathrm{ROE}$ & $\mathrm{X}_{5}=\mathrm{ROS}$ & $\mathbf{X}_{6}=\mathbf{P R}$ \\
\hline Minimum & $-9.008 \cdot 10^{-7}$ & -0.20 & -0.005 & -0.10 & 0.006 & -14.3 \\
\hline Maximum & $2.704 \cdot 10^{-7}$ & 21.60 & 0.030 & 0.02 & 0.010 & 14.2 \\
\hline Average & $-10^{-7}$ & 10.70 & 0.0065 & -0.0267 & 0.008 & 1.6 \\
\hline \multicolumn{7}{|c|}{$\begin{array}{l}\text { Frequency of appearance the factor variables in regression equations } \\
\text { (number of cases from all available) }\end{array}$} \\
\hline Positive values & 3 from 6 & 1 from 2 & 2 from 4 & 1 from 3 & 2 from 2 & 2 from 4 \\
\hline Negative values & 3 from 6 & 1 from 2 & 2 from 4 & 2 from 3 & - & 2 from 4 \\
\hline
\end{tabular}

\section{Conclusions}

The paper analyzes the relationship between insurance costs, performance and competitiveness indicators for 13 FIEs in
Ukraine. The results showed that the net income factor NI is present in 9 out of 12 calculated regression equations for insurance costs IC, the penetration ratio PR - in 6 regression equations, return on assets ROA - in

Copyright (C) 2021 Author(s), published by Vytautas Magnus University. This is an open access article distributed under the terms of the Creative Commons Attribution Non-Commercial 4.0 (CC BY-NC 4.0) license, which permits unrestricted use, distribution, and reproduction in any medium provided the original author and source are credited. The material cannot be used for commercial purposes. 
4 regression equations. In other words, we showed that enterprises with bigger net income spend more money for insurance.

The analysis partially confirms the first hypothesis that FIEs with higher competitiveness are more prone to insurance. Such influence is determined by correlations of return on assets and insurance costs.

Also, only in three cases correlations between factor $S$ (share of an entity in a net income of all enterprises in a market) and indicator IC (insurance costs) exist with positive values of correlation coefficients.

The analysis does not confirm the second hypothesis regarding the correlation between the share of insurance costs IS and key performance indicators ROA, ROE, ROS. The effect is obtained only for 4 correlations; whereas only in 2 cases such correlations have positive values of correlation coefficients.

\section{Acknowledgements}

The research is supported by the Ministry of Education and Science of Ukraine (certification 0117U001246, order №198 dated 10.02.2017, research head - Prof. Lada Shirinyan).

\section{References}

Akinrinola, O.O. and Okunola, A.M. (2014). Effects of Agricultural Insurance Scheme on Agricultural Production in Ondo State // Russian Journal of Agriculture and Social Sciences, 4(28), 3-8.

Zhao, Y. and Preckel, P. (2016). An empirical analysis of the effect of crop insurance on farmers' income // China Agricultural Economic Review, 8 (2), 299-313.

Lorant, A., and Farkas, M.F. (2015). Risk management in the agricultural sector with special attention to insurance // Polish Journal of Management Studies, 11(2), 71-82.

Barath, L., Dokucheva, R. and Ferto, I. (2017). Demand for Farm Insurance Under Financial Constraints // Eastern European Economics, 55(6), 1-20.

Buckley, P.J., Pass, C.L., Prescott, K. (1988). Measures of International Competitiveness: A Critical Survey. // Journal of Marketing Management 4(2), 175-200.

Zibor-Nemes, A., Fogarasi, J., Molnar, A., Kemeny, G. (2018). Farmers' responses to the changes in Hungarian agricultural insurance system // Agricultural Finance Review, 78(2), 275-288.

Kvasko, A.V. (2017). Analiz metodiv otsinky konkurentospromozhnosti pidpryyemstva [Analysis of methods of estimation of enterprise competitiveness] // Naukovi zapysky - Scientific Papers, 1(54), 111-118 (in Ukrainian).

Semenenko, O.H. (2017). Analiz rozvytku kharchovoyi promyslovosti Ukrayiny [Analysis of food industry development in Ukraine] // Ekonomika ta upravlinnya - Economics and Management, 33(1), 168-182 (in Ukrainian).

Lobova, O. (2014). Efektyvnist strakhuvannya ryzykiv pidpryyemnytskoyi diyalnosti v ahrarnomu sektori [Effectiveness of business risk insurance in the agricultural sector] // Visnyk Kyyivskoho natsionalnoho universytetu imeni Tarasa Shevchenka: Ekonomika - Bulletin of Taras Shevchenko National University of Kyiv: Economics, 3(156), 70-76 (in Ukrainian).

Official Body Stock Market Infrastructure Development Agency of Ukraine. - Retrieved from: http://smida.gov.ua [2020 0208 .

Porter, M.E., Rivkin, J.W. (2012). The Looming Challenge to U.S. Competitiveness // Harvard Business Review 90 (3), 54-61.

Shirinyan, A.S., Shirinyan, L.V. (2019). Konkurentospromozhnist rynku bankivskykh posluh Ukrayiny: faktor masshtabu [Competitiveness of the Ukrainian banking market: a factor of scale] // Ekonomika Ukrayiny - Economy of Ukraine, 2(687), 37-48 (in Ukrainian).

State Statistics Service of Ukraine. - Retrieved from: http://www.ukrstat.gov.ua/ [2020 04 22] .

Friedli, R. (2017). Trends in the food industry and what they mean for insurance // Swiss Re. - Retrieved from: https://www.swissre.com/institute/research/topics-and-risk-dialogues/nutrition-and-agriculture/trends-in-the-food-industryand-what-they-mean-for-insurance.html [2019 12 02]. 